\title{
PERBEDAAN PENGETAHUAN, SIKAP DAN PERILAKU IBU SEBELUM DAN SETELAH KONSELING GIZI PADA BALITA GIZI BURUK
}

\author{
Desi Sofiyana, Etika Ratna Noer $\left.{ }^{*}\right)$ \\ Program Studi Ilmu Gizi Fakultas Kedokteran Universitas Diponegoro \\ Jl.Dr.Sutomo No.14, Semarang, Telp (024) 8453708, Email : gizifk@ undip.ac.id
}

\begin{abstract}
Background: Undernutrition is a condition where a person's nutritional state are lower than WHO 2005 standart which is <-3SD weight-to-age. Factors that caused undernutrition in children under five including food consumption, infectious disease, and mother's knowledge and attitudes about nutrition and feeding. Alternative approach to solve undernutrition problem is by improving knowledge, attitudes and behavior of mother through nutritional counseling program. The purpose of this study are to analize the knowledge, attitudes and behaviors differences before and after nutrition counseling on undernutrition toddler's mother.

Methods: This study is a quasi experiment with one group pre-post test design. The data has been gathered with in deep interview technique using questionnaire help and observation. 26 subjects has been choosen using total sampling method of the total population of mothers and children under five from undernutrition prevention program. The bivariate analysis for before and after nutrition counseling for knowledge and attitudes result was analized using Wilcoxon test.

Results: The results from this study after nutition counseling shown the increase in mother's knowledge and attitudes by 34,6\% and 57,7\%. There was an increase in mother behavior become good show with a lot of mother to apply suggestion from counselor.

Conclusions: Nutrition counseling has a significant effects to increase knowledge, attitudes and behaviors on malnutrition children under five's mother.
\end{abstract}

Key Words : knowledge; attitudes; behaviors ; nutrition counseling; undernutrition

\begin{abstract}
ABSTRAK
Latar belakang: Gizi buruk merupakan kondisi seseorang di mana status gizi berada di bawah standar, yaitu BB/U <-3SD WHO-2005. Faktor penyebab gizi buruk pada balita, antara lain konsumsi makanan, penyakit infeksi, pengetahuan dan sikap ibu tentang gizi serta perilaku ibu dalam pemberian makan. Salah satu cara menangani gizi buruk dengan meningkatkan pengetahuan, sikap dan perilaku ibu melalui program konseling gizi. Penelitian ini bertujuan menganalisis perbedaan pengetahuan, sikap dan perilaku ibu balita gizi buruk sebelum dan setelah konseling gizi.

Metoda: Penelitian ini merupakan Quasi Experimen dengan desain One Group Pre Post Test. Pengumpulan data dilakukan dengan teknik wawancara secara mendalam dengan kuesioner dan pengamatan saat konseling belangsung. Jumlah subyek sebanyak 26 orang yang dipilih dengan total sampling dari total populasi ibu dari balita yang mengikuti program penanggulangan gizi buruk. Konseling gizi dilakukan sebanyak 4 kali. Analisis bivariat sebelum dan setelah konseling gizi untuk pengetahuan dan sikap menggunakan uji Wilcoxon.

Hasil: Hasil penelitian menunjukkan setelah konseling gizi pengetahuan ibu meningkat sebesar 34,6\%, sedangkan sikap ibu meningkat sebesar 57,7\%. Peningkatan perilaku ibu setelah konseling gizi menjadi baik ditunjukkan sebagian besar ibu menerapkan anjuran yang diberikan oleh konselor.

Terdapat perbedaan antara pengetahuan dan sikap dan perilaku ibu sebelum dan setelah konseling gizi.

Simpulan: Konseling gizi mempengaruhi peningkatan pengetahuan, sikap dan perilaku pada ibu balita gizi buruk.
\end{abstract}

Kata Kunci :pengetahuan; sikap; perilaku ; konseling gizi; gizi buruk

\section{PENDAHULUAN}

Pertumbuhan yang terhambat akibat gizi buruk pada masa emas khususnya balita akan sulit diperbaiki saat dewasa. ${ }^{1}$ WHO tahun 2011 menyatakan $54 \%$ kematian yang terjadi pada balita disebabkan oleh keadaan gizi buruk. ${ }^{2}$ Prevalensi gizi buruk di Indonesia tahun 2010 menurut data Riskesdas sebesar $4,9 \%$, sedangkan provinsi Jawa Tengah pada tahun yang sama sebesar 3,3\%. Kondisi gizi buruk akan berdampak buruk terhadap perkembangan maupun pertumbuhan balita apabila tidak segera ditangani.

Gizi buruk secara langsung disebabkan rendahnya asupan zat gizi dan penyakit infeksi, sedangkan penyebab tidak langsung gizi buruk 
antara lain keterbatasan pengetahuan, sikap dan perilaku gizi, pola pemberian makanan, pola pengasuhan anak, kondisi kesehatan dan lingkungan serta ketersedian pangan di rumah tangga. ${ }^{4}$ Indikator status gizi yang digunakan untuk mengetahui keadaan gizi buruk yaitu $\mathrm{BB} / \mathrm{U}$ dengan $z$-score < -3 SD WHO-2005. ${ }^{5}$

Peran Puskesmas, Posyandu dan Dinas Kesehatan sangat penting untuk mendeteksi kejadian gizi buruk di masyarakat. Upaya Dinas Kesehatan pada masalah gizi buruk di Dinas Kesehatan Kota Semarang meliputi Pemberian Makanan Tambahan-Pemulihan (PMT-P), pemeriksaan kesehatan oleh tenaga medis dan demo masak, tetapi dari upaya yang sudah dilakukan masih ditemukan kejadian gizi buruk. Keadaan ini disebabkan karena kurangnya perhatian dari segi karakteristik ibu balita gizi buruk seperti pendidikan, pengetahuan, sikap dan perilaku ibu. Pengetahuan yang kurang tentang pemberian makan dapat mempengaruhi status gizi anak. ${ }^{6-8}$ Pengetahuan dapat mempengaruhi sikap seseorang, sedangkan sikap dapat mempengaruhi perubahan perilaku seseorang. Sehingga dapat disimpulkan pengetahuan dan sikap dapat mempengaruhi terbentuknya perilaku seseorang. ${ }^{9-}$ 11

Salah satu upaya menanggulangi gizi buruk melalui peningkatan pengetahuan, sikap dan perilaku seseorang dengan melakukan konseling gizi. $^{12}$ Konseling gizi adalah suatu proses komunikasi 2 (dua) arah antara konselor dan klien untuk membantu klien mengenali dan mengatasi masalah gizi. ${ }^{13}$ Ibu sangat berperan dalam terbentuknya pola perilaku makan balita, sehingga diharapkan terjadi perubahan perilaku dalam hal pemberian makan pada balita gizi buruk. ${ }^{14-16}$

Hasil penelitian Fiona melaporkan pendidikan gizi dapat meningkatkan pemahaman dalam memilih makanan yang sehat dan bergizi. ${ }^{17}$ Penelitian Demianus menunjukkan konseling yang dilakukan dua minggu sekali selama 3 bulan meningkatkan pengetahuan gizi ibu pada konseling individu yaitu dari $37,4 \%$ menjadi $42,9 \%$ dan pada konseling kelompok $38 \%$ menjadi $40,6 \%{ }^{18}$

Kota Semarang masih terdapat 33 balita berstatus gizi buruk dan saat ini ditangani Dinas Kesehatan Kota Semarang. Berdasarkan latar belakang tersebut penulis perlu melakukan penelitian eksperimen mengenai perbedaan pengetahuan, sikap dan perilaku ibu tentang pemberian makan pada balita gizi buruk sebelum dan setelah konseling gizi di Kota Semarang.

\section{METODE}

Jenis Penelitian ini merupakan penelitian semi kualitatif dengan rancangan quasi experiment one group pre post test design. Populasi penelitian ini adalah seluruh ibu dari balita gizi buruk yang terdata saat pelacakan Dinas Kesehatan Kota Semarang tahun 2012. Pemilihan subjek dilakukan dengan total sampling pada seluruh populasi dengan kriteria ibu memiliki balita dengan status gizi buruk ditandai dengan $\mathrm{BB} / \mathrm{U}<-3 \mathrm{SD}^{5}$, mengikuti program Dinas Kesehatan Kota Semarang dan mendapatkan konseling gizi. Jumlah subjek semula sebanyak 33 subjek tetapi 2 orang subjek pindah keluar kota, 1 orang balita subjek meninggal dunia, 4 orang subjek tidak mengikuti konseling gizi sebanyak 4 kali sehingga jumlah subjek yang diteliti yaitu sebanyak 26 subjek.

Konseling gizi dilakukan oleh seorang mahasiswa ilmu gizi Universitas Diponegoro. Sebelum perlakuan dilakukan pre-test pada subjek, subjek terpilih diberi perlakuan konseling gizi selama 4 kali dalam satu bulan dengan waktu \pm 30-60 menit untuk setiap kali sesi, dengan media leaflet. Setelah perlakuan, subjek diberikan posttest kemudian dilihat perbedaan pengetahuan, sikap dan perilaku sebelum dan setelah konseling gizi pada ibu balita gizi buruk.

Pengetahuan ibu adalah tingkat pemahaman ibu balita dalam memahami dan kemampuan menjawab pertanyaan mengenai pemberian makan kepada balita yang diperoleh dari wawancara menggunakan kuesioner sebanyak 10 pertanyaan, dengan ketentuan nilai 0 bila subjek menjawab salah, nilai 1 menjawab benar kemudian dilakukan penjumlahan skor dibagi jumlah pertanyaan dikali $100 \%$. Penilaian didasarkan menurut Ali Khomsan karena kuesioner yang digunakan merupakan modifikasi kuesioner Ali Khomsan. Subjek dikatakan berpengetahuan baik bila jawaban benar $>80 \%$, berpengetahuan cukup bila jawaban benar $60 \%-80 \%$ dan berpengetahuan kurang bila jawaban benar $<60 \%{ }^{19}$

Sikap ibu adalah kesiapan atau kesediaan ibu untuk merespon sesuatu tentang pemberian makanan pada balita. Sikap ibu dinilai menggunakan kuesioner yang yang ditandai pilihan: Setuju dan tidak setuju. Jawaban yang benar untuk pernyataaan sikap diberikan skor 1 sedangkan untuk jawaban pernyataan sikap yang salah diberikan skor 0. Subjek dikatakan bersikap baik bila jawaban benar $>80 \%$, bersikap cukup bila jawaban benar $60 \%-80 \%$ dan bersikap kurang bila jawaban benar $<60 \% .{ }^{19}$ 
Perilaku ibu adalah hal yang berhubungan dengan pemberian makan balita yang dilakukan dengan wawancara secara mendalam dan pengamatan saat konseling belangsung, sehingga dapat menggambarkan pola pemberian makan balita secara tidak langsung.

Analisis univariat bertujuan untuk mendiskripsikan karakteristik ibu balita, pengetahuan, sikap dan perilaku ibu tentang pemberian makan pada balita. Analisis bivariat untuk mengetahui perbedaan pengetahuan, sikap dan perilaku ibu sebelum dan setelah konseling gizi pada balita gizi buruk digunakan uji Wilcoxon.

\section{HASIL PENELITIAN}

Karakteristik Subjek Penelitian

Karakteristik subjek dalam penelitian ini dapat terlihat pada tabel 1 :

Tabel 1. Distribusi frekuensi karakteristik Ibu Balita

\begin{tabular}{lcc}
\hline \multicolumn{1}{c}{ Karakteristik Subjek } & n & \% \\
\hline Kelompok Umur & 1 & 3.8 \\
$<20$ tahun & 11 & 42.3 \\
$20-30$ tahun & 12 & 46.2 \\
$30-40$ tahun & 2 & 7.7 \\
$>40$ tahun & 26 & 100 \\
\hline Total & 3 & \\
\hline Pekerjaan & 19 & 11.5 \\
Buruh & 4 & 73.1 \\
Ibu Rumah Tangga & 26 & 15.4 \\
Wiraswasta & & 100 \\
\hline Total & 4 & \\
\hline Pendidikan & 5 & 15.4 \\
Sekolah Dasar/Sederajat & 14 & 19.2 \\
Sekolah & 3 & 53.8 \\
Pertama/Sederajat & Menengah & 11.5 \\
Sekolah Menengah Atas/Sederajat & 26 & \\
Perguruan Tinggi & & 100 \\
\hline Total & & \\
\hline
\end{tabular}

Berdasarkan hasil penelitian diketahui sebagian besar subjek $(88,6 \%)$ berusia $20-40$ tahun yang tergolong dalam usia produktif. Subjek dengan usia produktif lebih mudah untuk mengalami perubahan perilaku. Sebagian besar subjek $(73,1 \%)$ memiliki pekerjaan sebagai IRT (Ibu Rumah Tangga). Sebagian besar pendidikan subjek adalah SMA/sederajat $(53,8 \%)$.

\section{Pengetahuan dan Sikap}

Tabel 2. Distribusi Frekuensi Pengetahuan dan Sikap Pre dan Post

\begin{tabular}{|c|c|c|c|c|c|}
\hline & \multicolumn{2}{|c|}{ Pretest $(n=26)$} & \multicolumn{2}{|c|}{ Postest $(n=26)$} & \multirow[t]{2}{*}{$\mathbf{P}$} \\
\hline & $\mathbf{N}$ & $\%$ & $\mathbf{n}$ & $\%$ & \\
\hline \multicolumn{6}{|l|}{ Pengetahuan } \\
\hline Baik $(>80 \%)$ & 5 & 19.2 & 14 & 53.8 & \multirow{3}{*}{0,001} \\
\hline Culaup (60-80\%) & 14 & 53.8 & 11 & 42.3 & \\
\hline Kurang $(<60 \%)$ & 7 & 26.9 & 1 & 3.8 & \\
\hline \multicolumn{6}{|l|}{ Silsap } \\
\hline Baik $(>80 \%)$ & 6 & 23.1 & 21 & 80.8 & \multirow{3}{*}{$0,001^{2}$} \\
\hline Culap $(60-80 \%)$ & 17 & 65.4 & 4 & 15.4 & \\
\hline Kurang ( $<60 \%)$ & 3 & 11.5 & 1 & 3.8 & \\
\hline
\end{tabular}

Keterangan : a) Wilcoxon 
Hasil penelitian menunjukkan sebagian besar pengetahuan subjek sebelum konseling gizi sudah cukup, sedangkan setelah dilakukan konseling gizi sebagian besar pengetahuan subjek menjadi baik. Peningkatan pengetahuan dari kurang menjadi cukup sebanyak 4 subjek, kurang menjadi cukup 2 subjek sedangkan cukup menjadi baik sebanyak 7 subjek. Dari seluruh pertanyaan tentang pengetahuan sebagian besar subjek setelah konseling gizi dapat menjawab dengan benar pertanyaan tentang bentuk makanan sesuai usia anak, frekuensi pemberian makan dan pemberian makanan selingan. Hasil uji statistik diperoleh nilai $\mathrm{p}=0,001$ yang menyatakan terdapat perbedaan pengetahuan ibu tentang pemberian makan sebelum dan setelah konseling gizi.

Sikap subjek sebelum konseling gizi diketahui cukup sebesar $65,4 \%$, sedangkan setelah konseling gizi meningkat menjadi $80,8 \%$ bersikap baik. Peningkatan sikap dari kurang menjadi cukup sebanyak 1 subjek, kurang menjadi baik 2 subjek, sedangkan cukup menjadi baik sebanyak 13 subjek. Dari seluruh item pertanyaan tentang sikap sebagian subjek menyatakan setuju tentang bentuk makanan dan jenis bahan makanan yang diberikan sesuai usia. Hasil uji statistik diperoleh nilai $\mathrm{p}=0,001$, sehingga dapat dinyatakan terdapat perbedaan sikap ibu tentang sebelum dan setelah konseling gizi.

\section{Perilaku}

Hasil wawancara mendalam menunjukkan bahwa sebagian besar subjek mengalami perubahan perilaku pemberian makan pada balita setelah konseling gizi khususnya dalam hal meningkatnya frekuensi makan, bentuk makanan serta pemberian selingan. Perubahan perilaku subjek yang dapat diamati, antara lain ditunjukkan pada tabel 3.

Tabel 3. Gambaran Perubahan Perilaku subjek setelah dilakukan konseling gizi

\begin{tabular}{|c|c|c|c|}
\hline No & Subjek & Usia Balita & Perubahan Perilaku \\
\hline 1 & $\mathrm{~A}_{1}$ & 1 bulan & $\begin{array}{l}\text { Bayi subjek tergolong BBLR dan menderita megacolon serta } \\
\text { gangguan payudara ibu sehingga ASI tidak keluar, oleh karena } \\
\text { itu bayi diberikan susu kental manis encer dua kali sehari. Setelah } \\
\text { konseling gizi subjek berusaha memberikan bayi makanan } \\
\text { pengganti ASI yaitu susu formula dengan frekuensi delapan kali } \\
\text { setiap harinya. }\end{array}$ \\
\hline 2 & $\mathrm{~A}_{2}$ & 2 bulan & $\begin{array}{l}\text { Bayi mulai usia satu bulan sudah diberikan makanan padat dan } \\
\text { buah-buahan seperti nasi, arem-arem dan pisang setelah } \\
\text { diberikan konseling gizi ibu berusaha memberikan ASI karena } \\
\text { ASI tidak keluar maka diberikan susu formula dan masih } \\
\text { diberikan berbagai macam makanan padat walaupun dalam } \\
\text { jumlah kecil. }\end{array}$ \\
\hline 3 & $\mathrm{~A}_{3}$ & 5 bulan & $\begin{array}{l}\text { Subjek mulai mengenalkan makanan pendamping ASI seperti } \\
\text { bubur susu sejak usia empat bulan. Setelah itu bayi subjek } \\
\text { mengalami diare berkepanjangan yang menyebabkan berat badan } \\
\text { turun. Setelah konseling gizi ibu berusaha memberikan ASI, susu } \\
\text { formula dan masih diberikan makanan dalam jumlah kecil. }\end{array}$ \\
\hline 4 & $\mathrm{~A}_{4}$ & 7 bulan & $\begin{array}{l}\text { Sejak usia } 2 \text { bulan bayi sudah diberikan susu dan pisang lumat, } \\
\text { beberapa bulan kemudian bayi mengalami penurunan berat badan } \\
\text { karena diare. Sejak saat itu bayi susah makan dan minum. Oleh } \\
\text { karena itu ibu mengalami ketakutan mengenalkan makanan pada } \\
\text { bayi. Setelah konseling gizi ibu mulai berani mengenalkan } \\
\text { makanan pada bayi berupa pisang yang dilumatkan, alpukat yang } \\
\text { dihaluskan serta bubur bayi. }\end{array}$ \\
\hline 5 & $\mathrm{~A}_{5}$ & 8 bulan & $\begin{array}{l}\text { Bayi memiliki postur yang sangat pendek. ASI ibu yang tidak } \\
\text { keluar menyebabkan bayi hanya diberikan susu formula. Bayi ini } \\
\text { belum dikenalkan makanan karena ibu berpendapat bahwa susu } \\
\text { formula lebih baik diberikan daripada makanan. Setelah } \\
\text { konseling gizi ibu mulai mengenalkan anak dengan buah-buahan } \\
\text { seperti pisang dan jeruk walaupun dalam porsi kecil. }\end{array}$ \\
\hline 6 & $\mathrm{~A}_{6}$ & 6,5 bulan & Bayi subjek mempunyai riwayat penyakit penyakit jantung \\
\hline
\end{tabular}




\begin{tabular}{|c|c|c|c|}
\hline & & & $\begin{array}{l}\text { bawaan, down sindrom dan leukimia. Memasuki usia } 6 \text { bulan ibu } \\
\text { belum berani mengenalkan makanan pada bayi. Setelah } \\
\text { konseling gizi ibu mulai mengetahui sebaiknya bayi dikenalkan } \\
\text { dengan makanan pendamping ASI. }\end{array}$ \\
\hline 7 & $\mathrm{~A}_{7}$ & 7 bulan & $\begin{array}{l}\text { Bayi mempunyai riwayat penyakit sangat pendek. Bayi sehari- } \\
\text { hari diberikan ASI dan susu formula. Susu formula sendiri } \\
\text { diberikan karena volume ASI yang kurang. Kesulitan minum dan } \\
\text { lamanya menelan susu pada bayi menyebabkan ibu putus asa, } \\
\text { setelah konseling gizi ibu mulai lebih sering berusaha } \\
\text { memberikan minum bayi dan mulai mengenalkan biskuit bayi. }\end{array}$ \\
\hline 8 & $\mathrm{~A}_{8}$ & 6 bulan & $\begin{array}{l}\text { Bayi memiliki riwayat penyakit cardiomegali dan down sindrom. } \\
\text { Bayi diberikan makanan sejak usia } 1 \text { bulan, sejak saat itu bayi } \\
\text { mengalami penurunan berat badan dan diare. Kondisi yang tidak } \\
\text { segera tertangani menyebabkan bayi berstatus gizi buruk. Setelah } \\
\text { konseling gizi ibu mulai diperkenalkan kembali makanan } \\
\text { pendamping ASI seperti buah-buahan, bubur susu sehari } 3 \text { kali } \\
\text { sehari sebanyak 2-3 sendok. }\end{array}$ \\
\hline 9 & $\mathrm{~A}_{9}$ & 17 bulan & $\begin{array}{l}\text { Anak memiliki riwayat penyakit TB. Sebelum konseling anak } \\
\text { mengalami sulit makan, oleh karena itu subjek memberikan } \\
\text { makanan selingan, akan tetapi anak menjadi cepat kenyang dan } \\
\text { sering melewatkan makanan utama. Setelah konseling gizi anak } \\
\text { mengalami peningkatan frekuensi pemberian makan anak } \\
\text { menjadi } 3 \text { kali sehari disertai pemberian selingan makanan } \\
\text { seperti buah-buahan, roti, wafer dll. }\end{array}$ \\
\hline 10 & $\mathrm{~A}_{10}$ & 18 bulan & $\begin{array}{l}\text { Sebelum konseling gizi ibu memberikan makan apabila anak mau } \\
\text { dan meminta saja. Keadaan tersebut membuat kondisi bayi } \\
\text { mengalami penurunan berat badan. Karena sikap ibu yang tidak } \\
\text { aktif dan merespon terhadap konselor setelah konseling gizi ibu } \\
\text { tetap tidak mencoba memberikan makan anak sesuai jadwal } \\
\text { makan anak. }\end{array}$ \\
\hline 11 & $\mathrm{~A}_{11}$ & 21 bulan & $\begin{array}{l}\text { Anak memiliki riwayat penyakit ISPA. Anak mengalami } \\
\text { keterlambatan pertumbuhan seperti bicara dan berjalan sehingga } \\
\text { ibu kurang tanggap dalam pemberian makan. Setelah konseling } \\
\text { gizi ibu tetap memberikan anak dengan porsi kecil dan tidak } \\
\text { mengikuti saran untuk menambahkan minyak dan santan karena } \\
\text { anak tidak suka. Lebih sering memberikan jajanan anak daripada } \\
\text { makanan seperti nasi. }\end{array}$ \\
\hline 12 & $\mathrm{~A}_{12}$ & 18 bulan & $\begin{array}{l}\text { Postur anak sangat pendek. Anak selalu menolak diberikan } \\
\text { makan dan selalu meminta wafer. Setelah konseling gizi ibu } \\
\text { berusaha memberikan makan anak sesuai jadwal walaupun porsi } \\
\text { kecil. Selingan juga diberikan berupa buah, roti dan wafer. }\end{array}$ \\
\hline 13 & $\mathrm{~A}_{13}$ & 21 bulan & $\begin{array}{l}\text { Anak mengalami gigi jarang dan postur pendek. Sebelumnya ibu } \\
\text { kurang tanggap anak mengalami keterlambatan berbicara dan } \\
\text { berjalan sehingga apabila anak tidak meminta makan maka ibu } \\
\text { akan memberikan. Setelah konseling gizi ibu berusaha } \\
\text { memberikan makan } 3 \text { kali sehari dengan lauk dan sayur serta } \\
\text { ditambah susu formula. }\end{array}$ \\
\hline 14 & $\mathrm{~A}_{14}$ & 13 bulan & $\begin{array}{l}\text { Postur anak tidak sesuai umur dan sangat pendek. Perilaku ibu } \\
\text { yang acuh pada bayi dengan mengalah apabila anak menolak } \\
\text { makan mengakibatkan kondisi anak tumbuh tidak sesuai dengan } \\
\text { usianya, setelah konseling gisi ibu mulai menyadari pentingnya } \\
\text { makan bagi kesehatan anak dengan mencoba memberikan makan } \\
\text { sebanyak } 4 \text { kali sehari porsi kecil walaupun anak menolak dan }\end{array}$ \\
\hline
\end{tabular}




\begin{tabular}{|c|c|c|c|}
\hline & & & menangis, ibu tetap berusaha memberikan makan. \\
\hline 15 & $\mathrm{~A}_{15}$ & 20 bulan & $\begin{array}{l}\text { Setelah konseling ibu masih menghadapi susah makan pada anak } \\
\text { tetapi untuk mencegah bertambah buruknya kondisi anak } \\
\text { diberikan makanan selingan seperti buah, roti serta susu formula. }\end{array}$ \\
\hline 16 & $\mathrm{~A}_{16}$ & 20 bulan & $\begin{array}{l}\text { Sebelumnya kesibukan ibu menyita waktu untuk merawat anak } \\
\text { sehingga pemberian makan terkesan semaunya sendisi. Setelah } \\
\text { konseling gizi ibu mulai rajin memberikan makan pada anak dan } \\
\text { mengenalkan sayur pada anak disela kesibukannya berwirausaha. }\end{array}$ \\
\hline 17 & $\mathrm{~A}_{17}$ & 25 bulan & $\begin{array}{l}\text { Riwayat penyakit anak ISPA. Anak mengalami kesulitan makan, } \\
\text { sehingga pertumbuhannya tidak sesuai dengan usianya. Subjek } \\
\text { bekerja sehingga anak subjek dijaga oleh neneknya, sedangkan } \\
\text { nenek anak harus menjaga tiga orang cucunya. Nenek merasa } \\
\text { puas apabila anak sudah mengkonsumsi dua sampai tiga sendok } \\
\text { makan. Sikap nenek yang kurang bersahabat dengan konselor } \\
\text { menjadikan konseling gizi tidak berjalan dengan lancar sehingga } \\
\text { nenek hanya mendengarkan tanpa memahami. Oleh karena itu } \\
\text { setelah konseling gizi perilaku nenek tetap saja mengaku anak } \\
\text { mengalami kesulitan makan dan tidak mau berusaha } \\
\text { meningkatkan makan anak. }\end{array}$ \\
\hline 18 & $\mathrm{~A}_{18}$ & 34 bulan & $\begin{array}{l}\text { Riwayat penyakit anak berupa TB dan postur anak yang pendek. } \\
\text { Sebelum konseling gizi ibu memberikan makan dengan porsi } \\
\text { kecil. Sikap subjek terhadap konselor baik tetapi kondisi anak } \\
\text { yang menangis apabila subjek sedang konseling gizi membuat } \\
\text { subjek hanya menjawab dengan seperlunya saja dan menyetujui } \\
\text { saran konselor. Oleh karena itu setelah konseling gizi ibu masih } \\
\text { belum menerapkan saran dari konselor untuk meningkatkan } \\
\text { makan anak. }\end{array}$ \\
\hline 19 & $\mathrm{~A}_{19}$ & 24 bulan & $\begin{array}{l}\text { Sebelumnya anak susah makan kondisi ini diperparah dengan } \\
\text { kesibukan ibu sebagai pedagang sehingga makan anak tidak } \\
\text { teratur. Setelah konseling gizi ibu meningkatkan frekuensi makan } \\
\text { sebanyak } 3 \text { kali sehari dan mencoba memberikan selingan sehat } \\
\text { seperti buah kesukaan yaitu pepaya. }\end{array}$ \\
\hline 20 & $\mathrm{~A}_{20}$ & 20 bulan & $\begin{array}{l}\text { Kondisi anak yang lemah menyebabkan ibu tidak banyak } \\
\text { memberikan makanan agar anak tidak muntah. Setelah konseling } \\
\text { gizi mencoba memberikan makan anak dengan porsi kecil tapi } \\
\text { sering serta menambahkan susu formula. }\end{array}$ \\
\hline 21 & $\mathrm{~A}_{21}$ & 32 bulan & $\begin{array}{l}\text { Riwayat penyakit anak menderita down sindrom. Subjek yang } \\
\text { masih muda tidak mau mengurus sendiri anaknya sehinga } \\
\text { dititipkan ke neneknya. Kondisi anak yang melemah dan susah } \\
\text { menelan menyebabkan tidak mau mengkonsumsi nasi lagi serta } \\
\text { berdampak berat badan anak menurun. Kondisi nenek yang sudah } \\
\text { tua menyebabkan kesulitan membaca dan mengerti apa yang } \\
\text { disarankan konselor sehingga setelah konseling gizi nenek masih } \\
\text { memberikan bubur dalam porsi kecil dan mulai mengenalkan } \\
\text { nasi sedikit. }\end{array}$ \\
\hline 22 & $\mathrm{~A}_{22}$ & 31 bulan & $\begin{array}{l}\text { Riwayat penyakit anak girang. Lokasi rumah yang jauh dari kota } \\
\text { menyebabkan subjek kesulitan untuk mendapatkan makanan } \\
\text { yang bervariasi. Sebelum konseling gizi anak hanya diberikan } \\
\text { makan sesuai dengan permintaan. Subjek mengalami kesulitan } \\
\text { dalam membaca dan memahami anjuran konselor sehingga } \\
\text { setelah konselor subjek masih belum dapat mempraktekkan apa } \\
\text { yang disarankan konselor. }\end{array}$ \\
\hline 23 & $\mathrm{~A}_{23}$ & 50 bulan & Sebelumnya ibu mengalami keputusasaan dalam pemberian \\
\hline
\end{tabular}




\begin{tabular}{|c|c|c|l|}
\hline & & $\begin{array}{l}\text { makan ataupun susu formula. Setelah konseling gizi ibu berusaha } \\
\text { memberikan makan dalam porsi kecil tapi sering serta diberikan } \\
\text { selingan roti, biscuit dan susu formula. }\end{array}$ \\
\hline 24 & $\mathrm{~A}_{24}$ & 34 bulan & $\begin{array}{l}\text { Penyakit yang diderita anak yaitu TB. Kondisi sakit yang diderita } \\
\text { menyebabkan berat badan anak turun drastis, setelah kosnseling } \\
\text { gizi ibu berusaha memulihkan kondisi anak dengan memberikan } \\
\text { makan sesuai kemampuan anak disertai selingan. Susu formula } \\
\text { belum diberikan lagi karena menyebabkan diare pada anak. }\end{array}$ \\
\hline 25 & $\mathrm{~A}_{25}$ & 36 bulan & $\begin{array}{l}\text { Sebelumnya anak susah dan menolak untuk makan. Setelah } \\
\text { konseling gizi ibu berusaha memberikan makan anak diserati } \\
\text { dengan bermain dan berjalan-jalan. }\end{array}$ \\
\hline 26 & $\mathrm{~A}_{26}$ & 30 bulan & $\begin{array}{l}\text { Riwayat penyakit anak yaitu down sindrom. Sebelumnya anak } \\
\text { diberikan makan semaunya saja, setelah konseling gizi anak } \\
\text { diberikan makan sesuai jadwal makan sebanyak 3 kali sehari } \\
\text { dengan nasi, lauk dan sayur serta cemilan biscuit sedikit. }\end{array}$ \\
\hline
\end{tabular}

Berdasarkan hasil wawancara sebelum dilakukan konseling gizi terdapat ibu balita usia 1 bulan memberikan makanan dini pada anak berupa nasi dan arem-arem. Hasil pengamatan langsung menunjukkan salah satu ibu menyuapi balita dengan jajanan arem-arem. Setelah konseling gizi perilaku ibu mengalami perubahan dengan memberikan bentuk makanan yang sesuai yaitu makanan cair. Payudara ibu mengalami gangguan sehingga tidak dapat mengeluarkan ASI, oleh karena itu diberikan susu formula.

“...Sekarang adek sudah mau minum susu mbak, sehari bisa minum 8 kali susu segini (menunjukkan cc botol), sekarang sudah ndak tak kasih makan kan belum boleh umur segini katanya mbak kemarin..."

Hasil wawancara menunjukkan terdapat pendamping ASI, mereka hanya diberikan ASI dan ibu balita usia 8 bulan, sebelum konseling gizi susu formula saja sesuai permintaan balita.

balita belum dikenalkan dengan makanan

“...Belum saya kasih makan mbak soalnya takut muntah mending saya kasih susu aja, tapi susu aja juga susah masuknya. Yasudah saya kasih aja kalau anaknya mau..."

Setelah konseling gizi perilaku ibu balita makanan pendamping ASI berupa bubur susu dan mengalami peningkatan dilihat dari mulai biskuit yang diberikan 2 sendok 2 kali sehari. dikenalkan balita dengan buah yang dihaluskan,

“...Iya mbak sekarang sudah saya coba kasih pisang yang dikerok, alpukat, papaya pokoknya buah-buah dulu sesuai saran mbak, untungnya dia mau walaupun awalnya cuma dimainin. Kalau makan pisang 1 buah besar bisa habis sendiri..."

Balita dengan usia 13 bulan balita sebelum membiarkannya berlarut-larut. Ibu sudah merasa konseling ibu balita memberikan makan sesuai puas apabila balita hanya memakan satu sendok permintaan anak, sebagian besar balita usia ini makan saja. Sebagai pengganti makanan ibu hanya mengalami susah makan sehingga ibu balita memberikan selingan berupa wafer dan jajanan mengalami kesulitan untuk memberikan asupan kemasan lainnya yang nilai gizinya kurang dari yang sesuai dengan kebutuhan anak. Keadaan yang dibutuhkan.

tersebut membuat ibu balita pasrah dan

“...Wah susah mbak ini kalau makan...Jangankan setengah mangkok dua sendok aja udah bagus itu...Kalau saya paksa nanti akhirnya nangis dan muntah jadi ya saya biarkan saja yang penting sudah masuk sedikit...Kalau ke warung ya minta jajan saya kasih kadang suka makan wafer dan roti tapi dimakan seperempat terus dilepas. Susahlah pokoknya makannya..."

Setelah dilakukan konseling gizi perilaku anak menolak maka ibu akan merayu dengan cara ibu mengalami peningkatan ditunjukkan dengan ibu mulai memberikan makan anak 3 kali sehari tanpa menunggu permintaan dari balita, apabila makan sambil bermain agar anak dapat teralih perhatiannya. Selain itu ibu juga memberikan selingan seperti roti, buah dan susu. 
“...Ya Alhamdulillah sudah bisa makan 3 kali sehari walaupun beberapa sendok, yang penting saya telateni makan sambil main mobil-mobilan sama ajak keliling kampung biar semakin baik keadaannya. Kadang saya beri selingan 2 kali sehari seperti dileaflet kayak pisang, kates yang mudah didapat sama roti..."

Balita usia 36 bulan sebelum konseling gizi ibu balita mengalami kesulitan yaitu balita yang susah makan. Keadaan tersebut membuat ibu balita merasa jenuh dan menghentikan pemberian makan apabila anak menolak. Setelah konseling

gizi terdapat peningkatan perilaku ibu yaitu mencoba memberikan makan anak sesuai kebutuhannya 3 kali sehari ditambahkan dengan selingan.

\begin{abstract}
“...Saya ajak main dulu mbak habis itu saya suapi kalau ndak gitu ndak mau makan, pokoknya waktu makan saya ajak main sama jalan-jalan. Sekarang lebih mending dari pada dulu ndak mau makan sama sekali, sekarang pokoknya saya coba gimana caranya anak saya makan 3 kali sehari sama saya kasih cemilan minimal 2 kali sehari seperti contoh dipedoman makan anak... biar tambah-tambah gitu..."
\end{abstract}

Hasil wawancara dan pengamatan langsung menunjukkan sebanyak 20 subjek sebelum konseling gizi berperilaku kurang, setelah mendapat konseling gizi sebanyak 18 subjek mengalami peningkatan perilaku menjadi baik

\title{
PEMBAHASAN
}

\section{Karakteristik Subjek Penelitian}

Pada penelitian ini terdiri dari 26 ibu yang memiliki balita dengan status gizi buruk $\mathrm{BB} / \mathrm{U}$ dengan $z$-score < -3 SD WHO-2005. ${ }^{5}$ Karakteristik ibu seperti kelompok umur, pekerjaan dan pendidikan merupakan beberapa faktor yang dapat mempengaruhi terbentuknya perilaku. Rerata umur ibu masih dalam kategori usia produktif, sehingga ibu akan lebih mudah untuk berpikir dan menerima informasi. ${ }^{21}$ Pada karakteristik pekerjaan yaitu sebagian besar ibu sebagai Ibu Rumah Tangga, dimana mempunyai lebih banyak waktu untuk menerima dan memahami informasi melalui konseling gizi, membaca leaflet serta mempraktekkan perilaku yang dianjurkan. Sedangkan pada karakteristik pendidikan sebagian besar subjek berpendidikan SMA/Sederajat, dimana pendidikan formal akan mempengaruhi tingkat pengetahuan gizi. Menurut teori perilaku Green tentang perubahan perilaku bahwa semakin tinggi pendidikan seseorang maka mereka semakin dapat menerima pembelajaran dan dapat merubah suatu perilaku. ${ }^{21,22}$

Perbedaan pengetahuan ibu sebelum dan setelah konseling gizi

Pengetahuan merupakan hasil tahu seseorang terhadap objek melalui indera yang dimiliki dan dipengaruhi oleh perhatian dan persepsi terhadap objek. ${ }^{21}$ Pengetahuan akan kandungan dan manfaat zat gizi makanan bagi kesehatan tubuh merupakan pertimbangan untuk mengkonsumsi makanan. ${ }^{23}$ Beberapa faktor yang

terbukti subjek dapat melaksanakan anjuran saat konseling gizi ditunjukkan dengan meningkatnya frekuensi makan anak yang didapat melalui wawancara secara mendalam dan pengamatan.

berpengaruh terhadap pengetahuan seseorang, meliputi: pendidikan, pekerjaan, informasi, dan pengalaman. $^{21}$

Pengetahuan ibu yang baik tentang gizi akan berdampak positif terhadap pola makan anak. Pola pemberian makan pada anak perlu dilakukan secara tepat karena kondisi anak berbeda dengan orang dewasa. Anak sedang mengalami perubahan dan perkembangan yang paling pesat dalam kehidupannya, yaitu perkembangan kematangan sistem pencernaan, kematangan organ-organ tubuh, otak dan jiwa. Pada masa ini orang tua perlu memiliki pengetahuan dan ketrampilan yang memadai dalam pemilihan dan cara pemberian makan anak. Penelitian yang dilakukan Heny menunjukkan bahwa terdapat hubungan yang signifikan $(p=0.003)$ antara pengetahuan ibu dengan pemberian makanan pada balita. ${ }^{24}$ Selain itu penelitian Apooh menunjukkan bahwa terdapat hubungan antara pengetahuan gizi ibu dengan status gizi balita. ${ }^{25}$

Berdasarkan hasil penelitian sebagian besar subjek sebelum dilakukan konseling gizi memiliki pengetahuan yang cukup, sehingga dapat disimpulkan bahwa ibu kurang maksimal mendapat informasi dari kader dan media massa atau elektronik tentang pemberian makan anak. Pengetahuan minimal yang harus diketahui seorang ibu adalah tentang kebutuhan gizi, cara pemberian makan, jadwal pemberian makan pada balita, sehingga akan menjamin anak dapat tumbuh dan berkembang dengan optimal. ${ }^{26}$ 
Berdasarkan hasil penelitian diperoleh bahwa terjadi peningkatan pengetahuan ibu balita dimana sebelum dilakukan konseling gizi sebagian besar ibu balita memiliki pengetahuan cukup, kemudian setelah dilakukan konseling gizi sebagian besar ibu balita memiliki pengetahuan baik, khususnya dalam hal bentuk makanan, frekuensi makan dan pemberian makanan selingan.

Berdasarkan hasil penelitian Rasanen et al bahwa konseling gizi dalam waktu relatif singkat dapat meningkatkan pengetahuan gizi seseorang. ${ }^{27}$ Peningkatan pengetahuan subjek mempengaruhi ibu untuk berusaha memenuhi kebutuhan gizi anak. Hasil analisis wilcoxon diketahui p-value pengetahuan $\mathrm{p}=0,001$ sehingga dapat diartikan terdapat perbedaan pengetahuan sebelum dan setelah konseling gizi.

\section{Perbedaan sikap ibu sebelum dan setelah konseling gizi}

Sikap merupakan kesiapan atau kesediaan seseorang untuk bertingkah laku atau merespon sesuatu baik terhadap rangsangan positif maupun rangsangan negatif dari suatu objek rangsangan. ${ }^{11}$ Sikap bukan suatu tindakan atau aktivitas, akan tetapi merupakan faktor predisposisi bagi seseorang untuk berperilaku. ${ }^{10}$ Sikap seseorang dipengaruhi oleh faktor internal antara lain faktor psikologis dan fisiologis. Faktor eksternal berupa intervensi yang datang dari luar individu misalnya berupa pendidikan, pelatihan dan lainnya. Sikap subjek dalam pemberian makan akan mempengaruhi pola konsumsi seorang anak. Sikap ibu yang buruk tentang pemberian makan dapat menyebabkan pola konsumsi anak terganggu serta terjadinya gizi buruk pada anak.

Hasil penelitian menunjukkan bahwa sebelum konseling gizi sebagian besar sikap ibu balita cukup. Namun masih ditemukan sikap yang kurang pada ibu seperti tidak setuju kondisi gizi buruk harus segera ditangani, memperkenalkan makanan awal pada bayi dengan makanan semi cair, anak usia 12-24 bulan diberikan makanan lunak. Hasil penelitian setelah konseling gizi terdapat peningkatan sikap ditunjukkan sebagian besar ibu bersikap baik. Oleh karena itu, dapat disimpulkan bahwa pemberian konseling gizi dapat meningkatkan sikap seseorang. Berdasarkan penelitian Sheira et al yang menyatakan konseling gizi dapat meningkatkan pengetahuan subjek mempengaruhi perubahan sikap menjadi lebih positif. ${ }^{28}$ Konseling terbukti efektif mengubah sikap negatif menjadi positif seperti hasil penelitian ini khususnya dalam bidang kesehatan. ${ }^{29}$
Perubahan sikap tersebut tidak terlepas dari faktor yang mempengaruhi yaitu pengalaman pribadi, kebudayaan, orang lain yang dianggap penting, informasi yang diterima dari berbagai sumber, emosi dari ibu sendiri serta fasilitas dan support dari keluarga termasuk suami. ${ }^{11,30}$ Sikap merupakan salah satu faktor yang mempengaruhi perilaku kesehatan seseorang. Perubahan sikap secara berkelanjutan dapat mengubah perilaku seseorang dimana perilaku pemberian makan yang baik dapat meningkatkan status gizi anak. ${ }^{25}$ Nilai $p$ value sikap ibu sebelum dan setelah konseling gizi sebesar 0,001, oleh karena itu dapat disimpulkan terdapat perbedaan sikap sebelum dan setelah konseling gizi.

\section{Perbedaan perilaku ibu sebelum dan setelah konseling gizi}

Penelitian Amrahu menunjukkan faktor penyebab gizi buruk berhubungan dengan pemberian makanan yang kurang memadai, tidak memberikan ASI eksklusif selama 6 bulan, dan terlambatnya memberikan makanan pendamping. ${ }^{31}$ Hasil penelitian ini menunjukkan bahwa sebelum diberikan konseling gizi perilaku ibu kategori masih kurang. Perilaku kurang ditunjukkan dengan pemberian makan yang tidak tepat pada balita antara lain mengenalkan makanan terlalu dini atau terlambat, konsumsi bahan makanan yang kurang beranekaragam, kurang tersedianya makanan. ${ }^{32-34}$

Salah satu cara mengubah perilaku seseorang dengan pemberian informasi dan dukungan untuk meningkatkan pengetahuan ibu sehingga dapat di aplikasikan dalam kehidupan yaitu dengan konseling gizi. Perilaku yang didasari oleh pengetahuan akan bertahan lama dibandingkan dengan perilaku yang tanpa didasari oleh pengetahuan. ${ }^{11}$ Perilaku mengenai kesehatan dipengaruhi pengetahuan, sikap, kepercayaan, dan tradisi sebagai faktor predisposisi. Faktor pendukung seperti lingkungan fisik, prasarana, dan faktor pendorong yaitu sikap dan perilaku petugas kesehatan dan petugas lainnya. ${ }^{35}$

Hasil penelitian menunjukkan sebelum konseling gizi sebagian besar ibu berperilaku kurang seperti perilaku ibu yang memberikan bentuk makan, frekuensi pemberian makan yang kurang dari usia balita dan sering memberikan jajanan. Setelah konseling gizi sebagian besar perilaku ibu meningkat menjadi baik ditunjukkan dengan anak mulai diberikan bentuk makanan sesuai usia, pemberian makan sesuai kebutuhan serta membatasi selingan sebanyak 2 kali sehari. Hasil penelitian Podojoyo menyatakan bahwa konseling gizi dapat memberikan perubahan 
konsep dan perilaku subjek. ${ }^{36}$ Berdasarkan penelitian Pelto bahwa konseling gizi dapat memberikan dampak positif pada perubahan perilaku. ${ }^{37}$ Selain itu hal ini sesuai teori Health Belief Model yang menyatakan bahwa konseling dengan metode bertatap muka dan berdiskusi secara langsung akan memberikan hasil perubahan perilaku ke arah yang lebih baik. ${ }^{22}$

Pada penelitian ini sebelum konseling gizi pengetahuan dan sikap sebagian besar ibu sudah cukup sehingga setelah dilakukan konseling gizi perubahan perilaku akan mudah terjadi. Pengetahuan serta sikap ibu mempengaruhi perilaku seorang ibu dalam pemberian makan. ${ }^{31}$ Individu yang mendapat informasi baru akan mendapat pengetahuan, mengalami perubahan sikap, dan akan mengalami peningkatan perilaku. ${ }^{38}$

\section{KETERBATASAN PENELITIAN}

Keterbatasan penelitian ini yaitu penelitian hanya mengambil populasi ibu balita gizi buruk yang mengikuti program Dinas Kesehatan Kota Semarang sehingga memungkinkan adanya informasi yang tidak didapatkan peneliti secara lebih mendalam.

\section{SIMPULAN}

Pemberian konseling gizi dapat meningkatkan pengetahuan, sikap, dan perilaku ibu tentang pemberian makan pada balita gizi buruk.

\section{SARAN}

Berkaitan dengan hasil penelitian ini bahwa konseling gizi dapat meningkatkan pengetahuan, sikap dan perilaku ibu. Perlu dilakukan konseling gizi secara terprogram dan berkesinambungan kerjasama antara puskesmas dan Dinas Kesehatan Kota pada ibu balita gizi buruk untuk tercapainya keberhasilan program penanganan gizi buruk pada balita selanjutnya.

\section{DAFTAR PUSTAKA}

1. Badan Perencanaan Pembangunan Nasional RI. Rencana Aksi Nasional Pangan dan Gizi 20112015. Jakarta. Badan Perencanaan Pembangunan Nasional, Kementrian Negara Perencanaan Pembangunan Nasional.2010.

2. World Health Organization. World Health Statistics 2011.2011.

3. Departemen Kesehatan Republik Indonesia. Riset Kesehatan Dasar 2010. Jakarta: Badan Penelitian dan Pengembangan Kesehatan Kementerian Kesehatan RI.

4. Bapenas dan Unicef. Laporan Indonesia untuk persiapan End Decade Goal 2000.2000.
5. World Health Organization. WHO Child Growth Standards: length/height for age, weight for age, weight for length, weight for height, and body mass index for age. Methods and development. France: WHO. 2006:229.

6. Allen L, Gillespie S. What Works? A review of the efficacy and effectiveness of nutrition interventions. Standing Committee on Nutrition of the UN ACC/SCN Nutr Policy paper No. 19/Asian Development ADB Nutr Devel Ser No. 5. Geneva: ACC/SCN. 2001.

7. Engle PL. Infant feeding styles: barriers and opportunities for good nutrition in India. Nutr Rev. 2002;60(5 Pt 2):S109-14. Review. PubMed PMID: 12035847.

8. Moore AC, Akhter S, Aboud FE. Responsive complementary feeding in rural Bangladesh. Soc Sci Med 2006;62:1917-30.

9. Wardle J, Parmenter K, Waller J. Nutrition knowledge and food intake. Appetite. 2000;34:269-275.

10. Baranowski T, Cullen KW, Nicklas T, Thompson D, Baranowski J. Are current health behavioral change models helpful in guiding prevention of weight gain efforts? Obes Res 2003;11(suppl): 23S-43S.

11. Soekidjo N. Pendidikan Kesehatan dan Perilaku Kesehatan. Jakarta: Penerbit Rineka Cipta.2003:24-28.

12. Leksono Purnomo. Pengaruh pemberian makanan tambahan dan konseling gizi terhadap status gizi anak balita gizi buruk di kota Kendari dan kabupaten Konawe provinsi Sulawesi Tenggara. Selami IPS Edisi No 26 vol 2XIV 2009 Jan: ISSN 1410-2323.

13. Depkes RI. Petunjuk Teknis Tatalaksana Anak Gizi Buruk Buku II. Departemen Kesehatan Republik Indonesia. Jakarta: Depkes RI. 2003.

14. Faith MS, Scanlon KS, Birch LL, Francis LA, Sherry B. Parent-child feeding strategies and their relationships to child eating and weight status. Obes Res 2004,12:1711-22.

15. Opara DC, IB Umoh, M John. Effect of Nutritional Counseling and Micronutrient Supplementation on Some Biochemical Parameters of Persons Living with HIV and AIDS in Uyo, Nigeria. Pakistan Journal of Nutrition 2007.6(6):547-57.

16. Snetselaar L. Nutritional Counseling for Lifestyle Change. New York: CRC Taylor and Francis Group. 2006.

17. McCullough Fiona SW, Yoo Seunghee, Ainsworth Paul. Food Choice, Nutrition Education and Parental Influence on British and Korean Primary School Children. International Journal of Consumer Studies 2004 Jun; 28(3): 235-44.

18. Wonatorey D, Madarina J, MG Adiyanti. Pengaruh konseling gizi individu terhadap pengetahuan gizi ibu dan perbaikan status gizi balita gizi buruk yang mendapat PMT pemulihan di kota Sorong Irian 
Jaya.[Tesis] Yogyakarta: Universitas Gadjah Mada,2006.

19. Khomsan A. Teknik pengukuran pengetahuan gizi. Bogor: Institut Pertanian Bogor.2000. Hal: 30-35

20. Setiyanto Bowo, Della Rosa, Zahraini Yuni, Ester Yamima, ed. Pedoman pendamping keluraga menuju Kadarzi. Direktorat Bina Kesehatan masyarakat. Direktorat Gizi Kesehatan. Jakarta. 2007. Hal.7-11

21. Soekidjo N. Promosi kesehatan Teori dan Aplikasinya. Jakarta. Rineka Cipta.2005.

22. Contento Isobel R. Nutrition Education Linking Research, Theory, and Practice. 1st ed. United States of America: Jones and Barlett Publisher.2007.

23. Entos. Jenis Jenis,bentuk dan konsumsi suplemen pada pria dewasa di Jakarta Selatan. [skripsi]. Bogor: Institut Pertanian Bogor.2001.

24. Sulistiowati Heny. Hubungan Antara Pengetahuan Ibu Dan Pola Pemberia Makanan Pendamping ASI Dengan Status Gizi Balita Usia 4-24 Bulan Di Desa Sendangharjo Kecamatan Blora Kabupaten Blora. [skripsi]. Program Studi Kesehatan Masyarakat Universitas Negeri Semarang.2007.

25. Apooh, Lily Yaa dan Sturla Krekling. Maternal Nutritional Knowledge and Child Nutritional Status in The Volta Region of Ghanna. Blackwell Publishing, Maternal and Child Nutrition, I.2005.

26. Baliwati YF. Pengantar Pangan dan Gizi. Jakarta. Penerbit Swadaya, Cetakan I. 2004: 89

27. Rasanen $M$, Niinikoski $H$, Keskinen $S$, Heino $T$, Lagstrom $H$, Simell $O$, Helenius $H$, Ronnemaa $T$ et al. Impact of nutrition counselling on nutrition knowledge and nutrient intake of 7 to 9 yold children in an atherosclerosis prevention project. European Journal of Clinical Nutrition. 2004.p.162-171.

28. Schlair Sheira, Hanley Kathleen, Gillespie Colleen, Disney Lindsey, Kalet Adina, Darby $\underline{\text { PC, }}$ et al. How Medical Students' Behaviors and Attitudes affect the Impact of a Brief Curriculum on Nutrition Counseling. Journal of Nutrition Education and Behavior:2011.
29. Guise JM. The Efectiveness of Primary CaseBased Intervention to Promote Breastfeeding : Systematic Evidence Review and Meta-Analysis for the US Preventive Services Task Force. Annals of Faamily Medicine 2003,1:70-8

30. Azwar S. Sikap Manusia Teori dan Pengukurannya Edisi ke-2. Yogykarta: Pustaka Belajar;2003.

31. Amrahu S, Zemone T. risk factors for severe acute malnutrition children under the age of five: a case control study. Ethiop J Health Dev 2008: 21-5.

32. Bhandari N, Mazumder S, Bahl R, Martines J, Black RE, Bhan MK. An educational intervention to promote appropriate complementary feeding practices and physical growth in infants and young children in rural Haryana, India. Journal of Nutrition. 2004;134(9):2342-48.

33. Caulfield LE, Huffman SL, Piwoz EG. Interventions to improve intake of complementary foods by infants 6 to 12 months of age in developing countries: impact on growth and on the prevalence of malnutrition and potential contribution to child survival. Food and Nutrition Bulletin. 1999;20(2):183-200.

34. Shi L, Zhang J. Recent evidence of the effectiveness of educational interventions for improving complementary feeding practices in developing countries. Journal of Tropical Pediatrics. 2011;57(2):91-8.

35. Soekidjo N. Promosi Kesehatan dan Ilmu Perilaku. 1st ed. Jakarta. Rineka Cipt.2007.p.16-7,124.

36. Podojoyo, Susyani, Nuryanto. Konseling Gizi Terhadap Penurunan Berat Badan Remaja Overweight dan Obes di Kota Palembang. Jurnal Pembangunan Indonesia.2007.

37. Gretel H. Pelto, Ina Santos, Helen Gonc, alves, Cesar Victora, Jose Martines, Jean Pierre Habicht. Nutrition Counseling Training Changes Physician Behavior and Improves Caregiver Knowledge Acquisition. J. Nutr. 2004(134): 357-62.

38. O’Brien G., Davies M. Nutrition knowledge and body mass index. Health Education Research 2007;22 (4):571-75. 